\title{
RELATIONSHIP BETWEEN BUDGETARY PLANNING AND FINANCIAL PERFORMANCE OF COUNTY GOVERNMENT OF KERICHO, KENYA
}

\author{
Margret Chepkorir ${ }^{1}$, Dr. Willy Rugutt ${ }^{2}$, Dr. Penina Langat ${ }^{3}$ \\ ${ }^{I}$ MBA, Department of Accounting and Finance, University of Kabianga - P.O Box 2030-20200, Kenya \\ ${ }^{2}$ Lecturer, Department of Accounting and Finance, University of Kabianga \\ ${ }^{3}$ Lecturer, Department of Accounting and Finance, University of Kabianga
}

Article DOI: https://doi.org/10.36713/epra7765

DOI No: 10.36713/epra7765

\begin{abstract}
Budgeting has become a fundamental issue for many organizations and business entities across the globe. Despite the availability of legal framework on budgetary planning in the public sector, County Governments are still facing challenges such as delays in payment to suppliers, budget deficit, stalled projects and poor development records. It is on this basis that this study sought to investigate the relationship between budgetary planning and financial performance of County Government of Kericho, Kenya. The study was guided by allocation of resources theory, institutional theory and expenditure theory. The study adopted a correlation survey research design. The target population for the study was 3,848 employees from 12 departments of the County Government of Kericho. Proportion method and simple random sampling technique were used to ascertain sample size for the study. Both secondary and primary data were used for data collection where secondary data was collected from records in the County Government offices and primary data collected through structured questionnaires. Validity was ensured by discussing the content of the questionnaire with the supervisors and subject experts before going to the field. Cronbach's alpha coefficient was used to determine the reliability of the research instrument which was found to be 0.873 which was considered ideal. Data was analyzed using descriptive and inferential statistics. Descriptive statistics was presented by frequency tables, charts and graphs while inferential statistics were presented by correlation and regression models. The findings established that there was significant statistical relationship between budgetary planning $(\beta=1.096$, $P<0.05)$. The study concluded that the independent variables understudy contributed 60.5 variation on financial performance $\left(R^{2}=0.605\right)$. The study recommends that for efficient budgetary planning the county government should set realistic revenue targets so as to ensure that expected expenditure matches expected incomes and also acquire and train staff involved in budget planning for efficient planning process.
\end{abstract}

KEY WORDS: Budgetary Process, Budgetary Planning, Financial Performance, County Governments in Kenya

\section{INTRODUCTION}

Budgeting is considered as an important exercise in every organization without which an organization will not achieve its objectives, (Kamau, Rotich, \& Anyango, 2017). Regardless of the complexity, the size of the organization or the sector of industry that the organization belongs to, its efficiency and financial performance is greatly influenced by budgets and proper budgetary systems (Suberu, 2010).
According to Babalola (2008) budgets provide the organization with means of translating the overall objectives of an organization into a set of actions that provide or establish source of funds and the manner in which the funds will be used. They also enable the organization to evaluate performance of the personnel who are entrusted with the use of such resources.

Effectiveness and efficiency of day to day operation of organization majorly depend on budgeting (Pimpong \&
(C) 2021 EPRA EBMS | www.eprajournals.com 
Laryea, 2016). Budgeting is a system or process that is meant to ensure achievement of activities which are concerned with organizational objectives and goals over a given period of time stipulated with the support of resource allocated. The budget plan integrates the functions of the organization that are essential to the success of the organization (Koech, 2015).

The main aim of any government is to provide essential goods and services to the public. This is done by various departments and ministries within it, that is the devolved government and national government (Maritim, 2013). For efficient delivery of these services, each department should develop and approve an expenditure plan that should be passed as legislation. This plan should contain a summary of revenues and expenditure which should be made in advance before the lapse of a financial year.

According to Widiyanti, (2019) citizens hold the government into account on how it allocates and uses the state resources through the budget. Accountability is evaluated according to established rules, practices and policies that are contained in the public finance management guidelines. Drake and Febozzi, (2010), indicate that budgeting facilitates effective use of available funds enhance better decision making in the organization and provide a bench making tool to evaluate organizational performance. The success of any budgeting process relates to identification of goals, allocating responsibility, implementing and controlling the process to ensure that the set goals are achieved.

Financial performance is a measure of how well an organization is doing in meeting its financial obligations over time. This measure can be used to compare similar companies in the same industry or one industry rom the other, (Sontag-Padilla, Staplefoote \& Morganti, 2012). According to Anderson (2011), financial stability of the county governments can be determined by their ability to generating enough resources to be able to render quality services, have maximum service delivery potential, have ability to pay staff, venders and creditors and also have the ability to manage credit risk.

Management practices that influence financial performance and their measurement differ from one county to another. It has been established that counties which do better in financial management practices have stronger internal controls, better budgetary planning processes which involves preparing and approving major budget planning policy documents as per the regulatory framework, havening in place an efficient staffing structure to carry out budget planning, encouraging public participation and putting in place elaborate strategies that ensure maximum revenue collection to meet revue targets, (Muli \& Rotich, 2016).
For the public sector to deliver efficiently and deliver to its promises to various stakeholders, it is important that resources are well managed.

\section{PROBLEM STATEMENT}

Budgeting is an important planning tool in any organization including county governments. Guidelines on how county governments and national government can generate and spend money are provided for by Public Finance Management Act (2012) under section 125 act which provides for budget planning processes that are to be followed in the counties including establishment of long term and short term plans in terms of revenue mobilization and expenditure. Despite the available regulations on budgetary planning, County Governments in Kenya still face financial challenges such as delays in paying suppliers, stalled projects and poor development records at county level due to budget deficits. These challenges raise a lot of questions whether budgetary planning in the county governments is a reality or a formality. Previous studies on budgetary planning and financial performance have not conclusively addressed how effective budgetary planning is linked to organizational financial performance. some studies have established that management structure and leadership styles at the county government are solely responsible for influencing financial performance while others have pointed out that resource mobilization and budgetary planning influence performance. It is in the midst of this of this controversy that this study sought to assess the relationship between budgetary planning and financial performance of the county government of Kericho.

\section{THEORETICAL FRAMEWORK}

The study was anchored on Allocation of resources theory. This theory as advanced by Petaraf and Barney (2003). The theory describes the manner in which organizations, nations, entrepreneurs and individuals share financial resources through budgetary processes to achieve financial objectives. For an organization to achieve a sustainable competitive advantage in terms of economic resources; they should possess some qualities such as rare, priceless, non substitutable and imperfectly imitable. Budgetary process therefore becomes necessary in allocating the little pecuniary government agencies resources, (Anantadjaya, 2008).

Resource allocation economic concept has proved to be an important concept in organizations management using the theory of the invisible hand. This resources allocation theory should be conducted through perfect competition. That is a balance between 
demand and supply of resources by corporates and individuals, (Petaraf, 2003). Financial resources are distributed by corporates through budgeting with an aim of meeting predetermined financial goals. This theory therefore assists organizations in allocating available financial resources through budgetary process and ensuring that organization's financial objectives are achieved efficiently and effectively.

\section{EMPIRICAL REVIEW}

Budgetary planning is considered as one of the main element in the budgeting system. The budgeting planning involves strategic planning, short and long term planning. Short term planning focuses on the current environmental condition including physical, human and financial resources. Several studies have been conducted to establish the relationship between budgetary planning and performance.

Tracy (2017) conducted a study on the influence of budget control, budget planning and small businesses financial performance in the United States of America. The study employed a correlational survey design. The study targeted all small scale traders comprised of 86 business leaders and managers in the Midwest town of the USA. Using online survey, data was collected from the accessible population of 77 business managers. Multiple linear regression models were employed in the study to assess the relationship between the study variables. the study findings established that budgetary planning greatly influenced the financial performance of small businesses. The study indicated that efficient budget planning can enable businessmen advance financial well-being of their enterprises.

Mon, (2019) conducted a research on the relationship between budgetary process and financial performance of Myanmar Oriental Bank (MOB). The main focus of the study was to assess the influence of budgetary planning, budgetary implementation and on performance of the bank. The research adopted descriptive survey design and purposive sampling technique to select a sample of 50 employees from the bank for the study. Regression and correlation models were used to establish the relationship between the research variables. The results revealed that there budgetary planning greatly influenced the effectiveness and efficient execution of budgets in organizations. Planning ensured that organizations had set standards which can help track and evaluate performance. The study also established that participatory budgeting and financial performance were strongly correlated.
Silva and Jayamaha (2012) did a study on apparel industry budgetary process in Sri- Lanka with an aim to establish whether budgetary processes had a significant influence on performance of the industry. The study employed a descriptive survey design with a targeted population of selected apparel factories and used both primary and secondary data. Regression and correlation coefficients revealed that budgetary planning had a significant relationship with the firm's performance. The research also found that participation of stakeholders in the budget making process enhanced the organization's performance.

Kamau, Rotich and Anyango (2017) conducted a study on the effect of budgetary process on budget performance; A case of Kenyatta National Hospital. The aim of the study was to establish the influence of planning and involvement in the process of budget making. The research employed a descriptive survey design and targeted 450 employees of Kenyatta national hospital who are involved in the budget making exercise. A questionnaire was used to collect primary data from 72 respondents who formed the sample size. Descriptive statistics were used to analyze quantitative data while content analysis was used to analyze qualitative day. The results showed that planning a budget and participation has a substantial impact on budget performance.

Opondo (2017) researched on determining the people's participation in county budgeting process in county governments of Kenya. The study adopted mixed methods research design and the study targeted Nairobi residents, senior county officials and ward administrators who are involved in planning and budget implementation. The study sample 113 respondents through purposive sampling technique, data was collected by use of interview schedule and data collected was analyzed by use of both quantitative and qualitative technique. The research findings indicated that there was no significance relationship between people participation and budget processing. The study recommended sensitization of public on the importance of participating on the budget processing.

\section{CONCEPTUAL FRAMEWORK}

The independent variable for the study was Budgetary planning while the dependent variable was financial performance of the county governments measures by quality of service delivery, rate of project completion and funds Absorption rate. 
Independent Variable
Dependent Variable

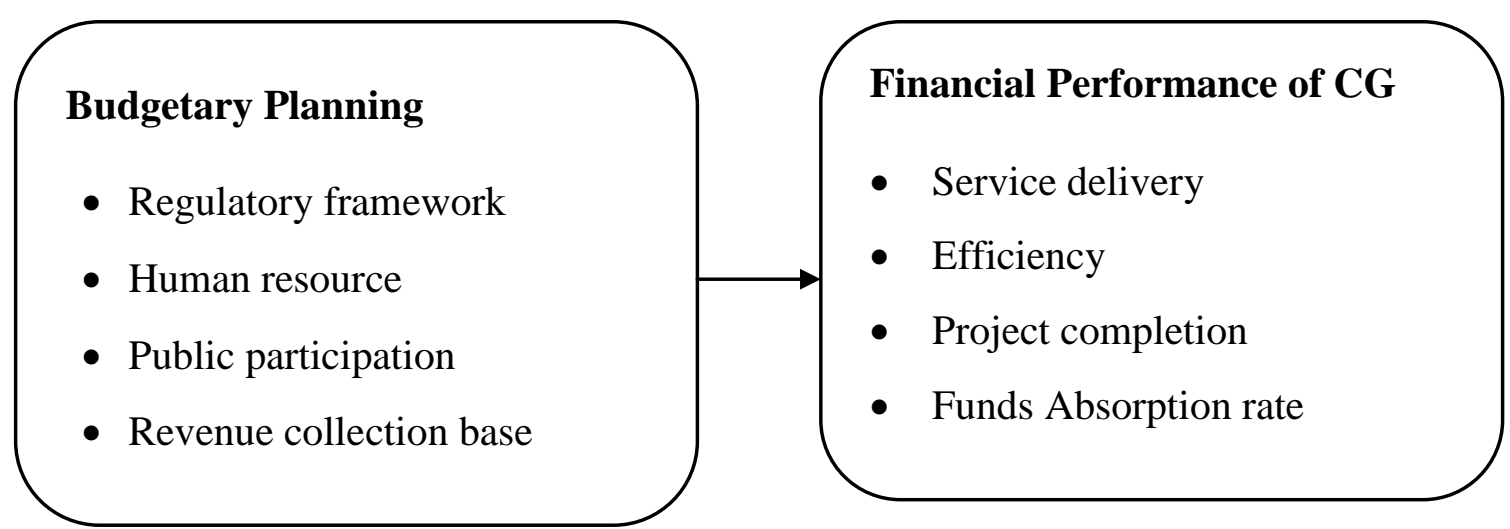

\section{RESEARCH DESIGN}

The study adopted both quantitative and qualitative research design to assess the relationship between budgetary process and financial performance of the county government of Kericho. The target population for the study was 3,848 employees drawn 12 different departments in the county government of Kericho. The study used Yamane (1967) formula and simple random sampling technique so select a sample of 362 employees who participated in the study.

\section{VALIDITY AND RELIABILITY OF THE} INSTRUMENTS

Content, construct, face and criterion validity were examined and enhanced to extensive literature review and consultation with subject experts including the lecturers from the department of accounting and finance of the University of Kabianga. Reliability on the other hand was determined using cronbach's alpha coefficient which was found to be 0.873 . according to Mugenda and Mugenda (2013) an alpha coefficient of 0.7 and above is deemed ideal for the study.

\section{RESULTS AND DISCUSSION}

Data was analyzed using descriptive and inferential statistics.

\section{DESCRIPTIVE STATISTICS}

A likert scale was used to present descriptive statistics where frequencies, means and standard deviation of the responses was determined.

Table 1: Frequency table for budgetary planning

\begin{tabular}{lccccc}
\hline $\begin{array}{l}\text { Statements on budgetary } \\
\text { planning }\end{array}$ & N & Minimum & Maximum & Mean & Std. Deviation \\
\hline $\begin{array}{l}\text { The county government } \\
\text { prepares and approves } \\
\text { major budget planning } \\
\text { policy documents as per the } \\
\text { budget cycle }\end{array}$ & 350 & 1.00 & 5.00 & 4.0771 & .92856 \\
$\begin{array}{l}\text { The county government sets } \\
\text { realistic revenue targets }\end{array}$ & 350 & 1.00 & 5.00 & 3.8686 & 1.21116 \\
$\begin{array}{l}\text { The county government has } \\
\text { elaborate strategies that } \\
\text { ensure maximum revenue } \\
\text { collection to meet revue }\end{array}$ & 350 & 2.00 & & & \\
targets & & & & & \\
\end{tabular}




\begin{tabular}{lccccc}
$\begin{array}{l}\text { The budgetary committee } \\
\text { invites for public } \\
\text { participation in budget }\end{array}$ & 350 & 1.00 & 5.00 & 4.0800 & 1.00109 \\
planning & & & & & \\
$\begin{array}{l}\text { The county government has } \\
\text { an efficient staffing }\end{array}$ & 350 & 1.00 & 5.00 & 3.9629 & .97021 \\
$\begin{array}{l}\text { structure to carry out budget } \\
\text { planning }\end{array}$ & & & & & .74840 \\
$\begin{array}{l}\text { Good budget planning leads } \\
\text { to efficient service delivery }\end{array}$ & 350 & 1.00 & 5.00 & 4.4914 & \\
$\begin{array}{l}\text { Valid N (list wise) } \\
\text { Source: Field Data }\end{array}$ & 350 & & & & \\
\hline
\end{tabular}

Source: Field Data (2021)

From the data in Table 1, the study established that majority of the respondents agreed that the county government prepares and approves major budget planning policy documents as per the budget cycle with a mean of 4.0771 and a standard deviation of 0.928 . On whether the county government sets realistic revenue targets, majority of the respondent were neutral with a mean of 3.8686 and a standard deviation of 1.2111. On if the county government has elaborate strategies that ensure maximum revenue collection to meet revue targets, majority of the respondents agreed with a mean score of 4.014 with a variance of 1.0. majority of the respondents also agreed that the budgetary committee invites for public participation in budget planning. This was indicated by a mean of 4.08 with a variance of 1.0. Majority of the respondents were neutral as to whether the county government had an efficient staffing structure to carry out budget planning. This was indicated with a mean of 3.962 with a standard deviation of 0.97 and Finally, majority of the respondents agreed that good budget planning leads to efficient service delivery $($ mean $=4.4914, \mathrm{SD}=0.74)$. These findings were similar to those of Tracy (2017) in a study to examine the influence of budget control, budget planning and small businesses financial performance in the United States. The study established that budget planning had a high positive significant relationship with financial performance of the firms' understudy.

This finding concur with those of Silva and Jayamaha (2012) who established that proper budget planning and efficient budget had significant influence on performance of government parastatals. However, the current study found that good budget planning assist in efficiency in service delivery. Similarly, Mon (2019) found that budgetary planning greatly influenced the effectiveness and efficient execution of budgets in organizations. This was linked to tracking and evaluation of performance based on set standard in planning process.

\section{INFERENTIAL ANALYSIS}

Table 2: Regression Coefficient

\begin{tabular}{|c|c|c|c|c|c|c|c|}
\hline \multirow{3}{*}{ Model } & \multicolumn{4}{|c|}{ Coefficients } & \multirow{3}{*}{ Sig. } & \multirow{2}{*}{\multicolumn{2}{|c|}{$\begin{array}{l}\text { Collinearity } \\
\text { Statistics }\end{array}$}} \\
\hline & \multicolumn{2}{|c|}{$\begin{array}{l}\text { Unstandardized } \\
\text { Coefficients }\end{array}$} & \multirow{2}{*}{$\begin{array}{c}\begin{array}{c}\text { Standardized } \\
\text { Coefficients }\end{array} \\
\text { Beta }\end{array}$} & \multirow[t]{2}{*}{$\mathbf{t}$} & & & \\
\hline & B & $\begin{array}{l}\text { Std. } \\
\text { Error }\end{array}$ & & & & $\begin{array}{l}\text { Toler } \\
\text { ance }\end{array}$ & VIF \\
\hline $1 \quad$ (Constant) & 0.861 & 0.185 & & 4.651 & 0.000 & & \\
\hline $\begin{array}{l}\text { Budgetary } \\
\text { Planning }\end{array}$ & 1.096 & 0.096 & 0.879 & 11.375 & 0.000 & 0.192 & 5.221 \\
\hline
\end{tabular}

a. Dependent Variable: Financial Performance of County Governments

Source: Research Data, (2021)

The findings in Table 2 above indicate that budgetary planning has a strong significant relationship with financial performance of the county government of Kericho, $(\beta=1.096, \mathrm{P}<0.05)$.

(C) 2021 EPRA EBMS | www.eprajournals.com 


\section{SUMMARY}

The study established that budgetary planning had a positive significant relationship with financial performance $(\beta=0.431,<0.05)$. The study revealed that the county government prepared and approved major budget planning policies as per the budget cycle. However, the government was not so keen on setting realistic revenue targets. The county government had in place elaborate revenue collection strategies that ensured maximum revenue collection. Finally, it was revealed that there was adequate participation in the budgeting process.

\section{CONCLUSION}

The study concluded that the county had an efficient and elaborate budgetary planning practices. This is because the county prepared budget planning policy as per the budget cycle. The county also had developed strategies that ensured maximum revenue collection and that the county government had in place an efficient staffing structure to carry out budget planning.

\section{RECOMMENDATION}

Based on the conclusions of the study that found a positive significant relationship between budgetary planning and financial performance of the county government of Kericho, the study recommended that the county government should set realistic revenue target so as to ensure that expected expenditure matches the expected incomes. The county government should also acquire and constantly train staff involved in budget planning for efficient planning process. Participation from other stakeholders should be involved as they enhance the budget planning process.

\section{REFERENCES}

1. Anantadjaya, S. P. (2008). Comparative literature study on the resource-based theory of the firm and knowledge-based theory of the firm. Jurnal Sistem Informasi, 3(1), 39-50.

2. Andersen, J., \& Samuelsson, J. (2016). Resource organization and firm performance: How entrepreneurial orientation and management accounting influence the profitability of growing and non-growing SMEs. International Journal of Entrepreneurial Behaviour \& Research, 22(4), 466484.

3. Babalola, R. (2008). Restructuring of National budget, key note address for appropriation Finance and Public Accounts Committee of senate and House of Retreat Representatives, held in Kaduna on March $10^{\text {th }} 2008$

4. Drake Peterson Pamela, and Fabozzi J. Frank (2010). The Basics of Finance: An Introduction to Financial Markets, Business Finance, and Portfolio
Management, John Wiley and Sons Inc., Hoboken, New Jersey

5. Kamau, J. K., Rotich, G., \& Anyango, W. (2017). Effect of budgeting process on budget performance of state corporations in Kenya: A case of Kenyatta National Hospital. International Academic Journal of Human Resource and Business Administration, 2(3), 255-281.

6. Koech, E. K. (2015). Financing of small and medium business enterprises in Kenya: A case of SMES in Ongata Rongai - Kajiado County (Doctoral dissertation). United States International UniversityAfrica, Kenya

7. Maritim, F. C. (2013). The effects of budgeting process on financial performance of commercial and manufacturing parastatals in Kenya(Doctoral dissertation) University of Nairobi, Kenya

8. Mon, A. K. (2019). Effects of Budgetary Control On Financial Performance in Myanmar Oriental Bank Limited (Doctoral dissertation) Yangon University of Economics.

9. Mugenda, A. G., \& Mugenda, A. (2013). Qualitative research methods.

10. Muli, B. M., \& Rotich, G. (2016). Effect of financial management practices on budget implementation of county governments: A case of Machakos County. The Strategic Journal of Business and Change Management, 3(4/40), 756-771

11. Peteraf, M. A., \& Barney, J. B. (2003). Unraveling the resource- based tangle. Managerial and decision economics, 24(4), 309-323.

12. Pimpong, S., \& Laryea, H. (2016). Budgeting and its impact on financial performance: The case of nonBank financial institutions in Ghana. International Journal of Academic Research and Reflection, 4(5), 12-22.

13. Silva, L. M. D., \& Jayamaha, A. (2012). Budgetary process and organizational performance of apparel industry in Sri Lanka. Journal of emerging trends in economics and management sciences, 3(4), 354-360.

14. Sontag-Padilla, L. M., Staplefoote, L., \& Morganti, K. G. (2012). Financial sustainability for nonprofit organizations: A review of the literature. RAND.

15. Suberu, S. B. (2010). Budgeting strategies in selected federal Polytechnic libraries in Nigeria. Samaru Journal of Information Studies Vol. 10.

16. Tracy, V. L., Basso, M. R., Marson, D. C., Combs, D. R., \& Whiteside, D. M. (2017). Capacity for financial decision making in multiple sclerosis. Journal of clinical and experimental neuropsychology, 39(1), 46-57. 